\title{
The Improvement of Student Communication and Mathematical Disposition Ability Through Problem Based Learning Model at UNIMED FMIPA Students
}

\author{
Glory Indira D. Purba ${ }^{1}$ and Edy Surya ${ }^{2}$ \\ \{glous_poerba@yahoo.com ${ }^{1}$ and edy_surya71@yahoo.com ${ }^{2}$ \} \\ Fakultas Matematika dan Ilmu Pengetahuan Alam Universitas Negeri Medan ${ }^{1,2}$ \\ Jl. Willem Iskandar Psr. V Medan Estate 20221, Indonesia
}

\begin{abstract}
The active involvement of students in learning must be supported by providing special activities that are student-centered so that they can do "doing math" to find and build mathematics facilitated by lecturers. One aspect of "doing math" is to improve mathematical communication skills. The existence of communication skills will certainly bring students to a deep mathematical understanding of mathematical concepts.In addition to mathematical communication skills, an attitude that must be possessed by students is needed, including appreciating the beauty of mathematics, having high curiosity and learning mathematics. With such an attitude, students are expected to develop mathematical abilities, use mathematics to solve problems faced in their lives, and can develop mathematical dispositions. This research conducted on students of FMIPA with the aim of: (1) knowing students' mathematical communication skills taught by using problem based learning learning model and talking learning model; (2) knowing the differences in students' mathematical disposition abilities taught using Problem Based Learning model and talking learning model; (3) produce a mathematical learning device in the form of an appropriate LAS used to improve students' mathematical communication; (4) produce teaching materials in the form of textbooks with appropriate problem-based learning model used to improve students' mathematical communication
\end{abstract}

Keywords: Mathematical communication, mathematical disposition, Problem Based Learning

\section{Introduction}

Mathematics as a means of scientific thinking is needed to develop the ability to think logically, systematically and critically. Similarly, mathematics is the basic knowledge needed to support success in higher education, even needed by everyone in everyday life. However, the quality of education has not shown the expected results. Constraints faced in the learning process of mathematics are the lack of interesting teaching materials for students and also the low ability of students to communicate mathematically to solve problems given. If the learning resources are less attractive and seem monotonous, it will reduce the quality of learning so that students' understanding of the material being taught becomes hampered.

One of the initial activities in improving learning is designing learning tools that refer to a model to facilitate learning. Learning design can be used as a starting point for efforts to improve the quality of learning. This means that the improvement of the quality of learning 
must begin with improving the quality of learning design, and designing learning with a system approach. In addition to learning devices, factors that influence the low quality of education include student mathematical communication skills. However, in the field shows students' mathematical communication skills are still low. The low mathematical communication of students can be seen with the low results achieved by students if given questions that are different from the existing examples. Students who know the basic concepts are not able to connect between conditions that are related to solving different problems.

The learning model provided so far still gives an impression that is not good for students and can educate them to be individualistic. They are more likely to view mathematics as a collection of rules and exercises that can bring boredom, because students' activities only repeat procedures or memorize algorithms without being given the opportunity to interact more with others. Thus most of the activities of students are practicing solving problems. Whereas what is desired is to be an independent student, and able to face challenges. The active involvement of students in learning must be supported by providing special activities that are student-centered so that students can do "doing math" to find and build mathematics facilitated by the teacher / lecturer.

From the statement above, one aspect that is emphasized in the curriculum and NCTM is to improve students' mathematical communication skills. Mathematical communication skills are basically goals and learning outcomes that will be achieved in learning at any level, therefore mathematics learning should always be aimed at the realization of mathematical communication skills so that in addition to mastering mathematics well students also perform optimally. In addition, the low learning competence of mathematics is also influenced by the lack of active participation of students in classroom learning. This greatly inhibits students from solving problems. This participation is closely related to students' mathematical communication skills. The low mathematical communication skills make it difficult for students to digest the questions given so they cannot solve the problem. Mathematical communication skills refer to the indicators outlined above, namely presenting mathematical statements verbally, written, pictures, and diagrams.

From the assessment of the affective domain, it can be seen how important it is to increase mathematical dispositions in the learning-learning process of mathematics. In the teachinglearning process, mathematical dispositions can be seen from students' desire to change strategies, reflect, and carry out analysis until a solution is obtained. Students' disposition of mathematics can be observed in class discussions. For example, how much students want to learn mathematics, the desire to explain the solutions they obtain and maintain their explanations. However, the attention of the teacher / lecturer in the teaching and learning process towards students' mathematical dispositions is still lacking.

Recognizing the importance of mathematical communication and disposition skills the teacher / lecturer must strive for learning by applying learning models that can provide opportunities and encourage students to practice mathematical communication and disposition skills. In mathematics learning with the lecture approach, students' communication skills are still very limited only to short verbal answers to various questions posed by the lecturer. Lecturers can accelerate the improvement of mathematical communication by giving mathematical tasks in various variations. Mathematical communication will play an effective role when conditioning students to listen actively as well as they talk about. Therefore, the change in learning view from the teacher teaching to students learning has become the main focus in every mathematics learning activity.

Many learning models can be used to develop students' abilities. The learning model used should be able to help students to solve their problems independently. Here requires the role of 
lecturers to be able to bring their students to have this ability. The learning model chosen should be tailored to the methods, media and other learning resources that are considered relevant in conveying information and guiding students to be involved optimally, so that students can gain learning experience in order to develop their abilities such as mental, intellectual, emotional and social skills and or cognitive, affective and psychomotor. Thus the selection of appropriate learning models can arouse and encourage students to improve students' understanding of certain learning materials. In the teaching and learning process (PBM) Problem based Learning learning models are very in line with the new paradigm of education. This learning is a systematic and structured learning strategy. For that reason, one of the solutions offered in improving the mathematics learning process, especially to improve the mathematical communication and disposition skills of FMIPA Unimed students is by using the Problem Based Learning learning model.

\section{Review Of Literature}

\subsection{Problem Based Learning Model}

Problem Based Learning (PBL) is a learning model that uses real world problems as a context for learning about critical thinking and problem solving skills, as well as acquiring essential knowledge and concepts from subjects. Ibrahim, et al (2015: 3) states that Problem Based Learning (PBL) is learning that presents to authentic and meaningful problem situations that can facilitate them in conducting investigations and inquiry. Likewise Arends (2015: 56) problem-based learning is a learning model in which students work on authentic problems with the intention to compile their own knowledge, develop inquiry and higher level thinking skills, develop independence and confidence.

From the opinions of experts taken the conclusion of problem-based learning is a learning approach that uses the problem as a starting point for learning. Problems that can be used as a learning tool are problems that meet the real world context, which are familiar with the daily lives of students. Through these contextual problems students rediscover knowledge of essential concepts and ideas from the subject matter and build them into cognitive structures.

Problem-based learning characterized as follows:

a. Submission of Problems or Questions.

Problem-based learning organizes learning around questions and social problems that are important for students and society. The question or problem is authentic (real) for students and does not have a simple answer. The question or problem must meet the following criteria: authentic, mystery, meaningful, broad, and useful

b. Focusing on Interdisciplinary Linkages

Problems raised in problem-based learning may be centered on certain subjects. The proposed problem should be truly authentic so that in the solution students review the problem from many aspects or relate it to other disciplines.

c. Authentic investigation

Problem-based learning requires students to conduct authentic investigations to find real solutions to real problems. Students must analyze and define problems, develop hypotheses and make predictions, collect and analyze information, conduct experiments (if necessary), make references, and form conclusions.

d. Produce Products / Works and Showcase them 
Problem-based learning requires students to produce certain products in the form of works and demonstrations that explain or represent the form of problem solving found. The product can be in the form of reports, physical models, videos, or computer programs. The work is displayed by students in front of his friends.

\section{e. Collaboration}

Problem-based learning is characterized by students working with each other in small groups. The advantages of working together in small groups among which students can give each other motivation to engage in complex tasks and increase opportunities to share inquiry and dialogue and to develop social skills and thinking skills.

\subsection{Talking Learning Model}

Talking learning model is a teaching center model. According to Arends (2015: 294), this model is one of the teaching models specifically designed to support student learning processes related to well-structured declarative knowledge and procedural knowledge that can be taught with a step-by-step activity pattern.

The characteristics of the learning model (in Trianto, 2016: 46) are as follows:

(1) Objectives and student learning outcomes

Learning theorists generally distinguish two kinds of knowledge, namely declarative knowledge and procedural knowledge. Memorizing certain laws or formulas in the fields of mathematics, chemical physics is an example of simple deklaraif knowledge. Procedural knowledge requires mastery of prerequisite knowledge in the form of declarative knowledge. The teachers always want students to obtain both types of knowledge, so that they can do an activity and do everything successfully.

(2) Syntax or overall pattern and flow of learning activities.

Direct teaching according to Kardi (in Trianto, 2009) can take the form of lectures, demonstrations, training or practice, and group work. Direct teaching is used to convey lessons that are transformed directly by the teacher to students.

(3) Learning environment and management system

Direct teaching requires careful planning and implementation on the part of the teacher. The learning management system carried out by the teacher must ensure the involvement of students, especially paying attention to, listening to, and reciting (question and answer) planned. This does not mean that learning is authoritarian, cold, and humorless.

\subsection{The Ability of Mathematical Communication}

Communication skills of students is the ability of students to communicate mathematics that is learned as the content of the message that must be delivered. Thus, mathematical communication is the ability of students to communicate which includes the activity of using the skills of reading, writing, listening, studying, interpreting, and evaluating ideas, symbols, terms, and mathematical information observed through the process of listening, presenting, and discussing. Ansari (2013: 54) describes the notion of mathematical communication in an outline consisting of oral and written mathematical communication. Oral mathematical communication can be interpreted as a mutually interacting event (dialogue) that occurs in a classroom or small group environment, and there is a transfer of messages containing mathematical material that is being studied both between the teacher and students and between students themselves. While mathematical writing communication is the ability or skill of students in using their vocabulary, notation, and mathematical structure both in the form of 
reasoning, connection, and in problem solving. If we look at this understanding, communication in mathematics can be interpreted as an interconnected event / dialogue that occurs in a classroom environment, where a message transfer occurs. The message that is transferred contains about the mathematics material learned in class. The parties involved in communication events in the classroom are teachers and students. While the way to transfer messages can be done in writing or verbally. Therefore, with the discussion in groups, conversations that express mathematical ideas will help students to hone their minds so that they will understand mathematics better. The communication process also helps students develop their own language to express mathematical ideas, and help build understanding and accuracy of ideas and make them delivered to others.

Mathematical communication skills can occur when students: 1) express mathematical ideas through speech, writing, demonstration, and visualize them in different types, 2) understand, interpret, and assess ideas presented in writing, verbal, or in visual form, 3) construct, interpret and relate various representations of ideas and relationships. In this study, mathematical communication skills are limited to writing communication, which is seen from the aspect of (1) representations: writing mathematical situations or ideas into drawings, explaining in writing pictures into mathematical ideas, formulating mathematical ideas into the model mathematics, and (2) explanations: explain the procedure for settlement

\subsection{The Ability of Mathematical Disposition}

Mathematical disposition is a student's attitude towards mathematics that can be realized through his actions in completing mathematical tasks. Mathematical disposition is called Sumarmo (2014: 85) as a desire, awareness, tendency and strong dedication to students to think and act mathematically in a positive way. Student's disposition of mathematics is realized through attitudes and actions in choosing an approach to completing a task. Whether done with confidence, curiosity in finding alternatives, diligence, and students' tendency to reflect on their thinking.

Mathematical disposition is one factor that determines the success of student learning. Students need a disposition that will make them persistent with more challenging problems, to take responsibility for their own learning, and to develop good habits in mathematics. Unfortunately, teachers tend to reduce the burden of learning mathematics with a view to helping students even though it is something that is important for students.

As for seeing the mathematical disposition of students, can be done by making a disposition and observation scale. The disposition scale contains the statements of each of the disposition components. For example "to understand the question given, I tried to solve it in various ways". While through observation, students' dispositions can be seen whether there are changes when students get and work on the questions and assignments given. For example when the learning process is taking place it can be seen whether students in solving math problems are difficult to give up or keep trying in various ways so that they get the right answer.

Based on the mathematical disposition indicators that have been stated above, the indicators of mathematical disposition in this study are: (1) confident in using mathematics, (2) flexible in doing mathematical work (mathematical), (3) persistent and tenacious in doing math tasks, (4) having curiosity in mathematics, (5) reflecting on ways of thinking and performance on oneself in learning mathematics, (6) appreciating mathematical applications, and (7) appreciating the role of mathematics / opinions about mathematics. 


\section{Methods}

This study was a quasi experiment, that was a research means to know whether or not a result of something that is important to students, in other words, the experiment research was trying to search whether or not the causal realtion. Its implementation involves two groups of experiments, i.e. classes that are taught by using a model Problem Based Learning was referred to as experimental class $A$ and class being taught by using a model of talking called as an experimental class B. The design of the research using Pretest-Postest Control Group Design. The sample that has been taken was grouped by two group experiment i.e. the first group as experimental class of A and second group as experimental class of B. Both sample class give the pretest to find out the ability or students understanding about the material that will be taught before we do the learning and to retrieve the homogen sample.

\section{Research Procedure}

\subsection{Preparation Stage}

In the preparation stage, the activities carried out are as follows:

a. Determine the place and arrange a research implementation schedule that is adjusted to the schedule in the school.

b. Determine population and research sample.

c. Develop Student Worksheets

d. Prepare data collection tools, in the form of pretest and posttest.

\subsection{Implementation Phase}

At the implementation stage, the activities carried out are as follows:

a. Validating the research instrument questions then tested the validity of the test, reliability of the test, the level of difficulty of the problem.

b. Giving pretest to both classes to measure students' initial ability to the material to be taught in both classes and to obtain a homogeneous sample.

c. Conduct learning in two classes with the same material and time, only different learning models.

d. Provide the posttest to both classes to measure the level of mastery of the material that has been taught. The time and duration of the posttest implementation in both classes are the same.

\subsection{Final Stage}

In the final stage, the activities carried out are as follows:

a. Calculate the difference between the results of the pretest and the results of the posttest for each class.

b. Compare these differences by assessing and reviewing the process of answers.

c. Test hypotheses of students' mathematical communication and disposition abilities using $t$ statistics to determine whether the score difference is significant or not. 


\section{Relevant Research}

In connection with the improvement of the learning process through the use of Problem Based Learning learning models that aim to improve the ability of student communication and disposition, it has been carried out through several preliminary studies by the research team. Among them: Efforts to Improve Reasoning Ability and Mathematical Communication By Applying Discovery Learning Model assisted by Student Worksheets (Purba, 2018); Improvement of Mathematical Problem and Disposition Ability through Cooperative Learning Model Type TGT (Nuraina, 2013); Difference between Problem Solving Ability and Mathematical Communication Between Students Given Problem Based Learning and Direct Learning (Marzuki, 2014). Another similar study is the ordering theory test method for the development of calculus subject matter, learning innovations to improve mathematical reasoning skills by using coop-coop type cooperative models, and improving student learning outcomes with reciprocal teaching (Simanjuntak) learning strategies. And also the 2013 study by (Rajagukguk and Simanjuntak), Development of Mathematics Teaching Materials Based on Integrated Problems to Improve Critical Thinking Ability of Middle School Students. Suhendra's (2015) research results in his research on high school students concluded that student learning outcomes in aspects of mathematical communication skills for students who received problem-based learning in small study groups were significantly better than students who had classical problem-based learning as well as students who learned conventional.

Harijanto's (2013) research results are also not much different, namely the use of teaching material products with the application of Problem Based Learning shows an increase in student learning outcomes, which is indicated by differences in the mean scores of pre-test and post-test. In his research shows that the use of instructional material products from the development can increase student scores by $26.50 \%$.

Innovations made in these studies have succeeded in improving student learning outcomes and get a good response to the learning process that is not monotonous centered on the teacher / lecturer. Based on the experience of researchers who have also carried out research can ensure the success rate of high research plans. Researchers are experienced and successful in improving the learning process through the innovation of the use of learning methods and media. The results of the study have also been applied in the classroom as a contribution to the researchers for improving learning.

Acknowledgements. Athors retrieve the support from State University of Medan. Authors say thank you for the support from research institution of State University of Medan and the Faculty of Mathematics and Natural Science of thisuniversity

\section{References}

[1] Amir, M. T..: Inovasi Pendidikan Melalui Problem Based Learning. Bagaimana Pendidik Memberdayakan pemelajar di Era Pengetahuan. Jakarta : Kencana Prenada Media Grup. (2010)

[2] Arends, Richard I.: "Learning to Teach". New York: McGraw HillCompanies. (2015)

[3] Ansari, B.I.: Komunikasi Matematik. Banda Aceh: Yayasan Pena. (2013)

[4] Ansari, B.I.: Kontribusi Aspek Talking dan Writing dalam Pembelajaran untuk Mengembangkan Kemampuan Pemahaman dan Komunikasi Matematik Siswa. Makalah disajikan pada Seminar Nasional Matematika dan Kontribusinya terhadap Peningkatan Kualitas SDM dalam Menyongsong Era Industri dan Informasi, 15 Mei 2014, Bandung. (2014)

[5] Arikunto, S.: Dasar-Dasar Evaluasi Pendidikan, Bumi Aksara, Jakarta (2013) 
[6] Asikin, M.: Komunikasi Matematika dalam RME. Makalah. Yogyakarta:Seminar Nasional RME di Universitas Sanata Dharma. (2014)

[7] Dahar, R. W.: Teori-Teori Belajar. Erlangga, Jakarta (2016)

[8] Harijanto.: Meningkatkan Kemampuan Pemecahan Masalah Dan Komunikasi Matematika Melalui Pembelajaran Berbasis Masalah Dengan Pendekatan Kooperatif. Tesis. Medan: UNIMED (2013)

[9] Ibrahim, S., dkk.: Berbagai Pendekatan dalam Proses Belajar Mengajar. Edisi Ketiga. Jakarta: Bina Aksara. (2015)

[10] Mahmudi, A.: .Tinjauan Asosiasi antara Kemampuan Pemecahan Masalah Matematis dan Disposisi Matematis. Makalah Disajikan Pada Seminar Nasional Pendidikan Matematika FMIPA Universitas Negeri Yogyakarta: Yogyakarta. (2014)

[11] Marzuki.: Perbedaan Kemampuan Pemecahan Masalah dan Komunikasi Matematika antara Siswa yang diberi Model Pembelajaran Berbasis Masalah dengan Model Pembelajaran Langsung. Tesis. Medan: Program Studi Pendidikan Matematika Pasca Sarjana Universitas Negeri Medan: Medan (2014)

[12] Nurhadi, dkk.: Kontekstual dan Penerapannya dalam KBK. Universitas Negeri Malang: UM Press. (2014)

[13] National Council of Teachers of Mathematics (NCTM).: Curriculum and Evaluation Standards for School Mathematics.[Online]. Tersedia: http://www.nctm.org/focalpoints. [3 Mei 2018]. (1998)

[14] Nuraina.: Peningkatan Kemampuan Komunikasi dan Disposisi Matematis Siswa Melalui Model Pembelajaran Kooperatif Tipe Teams-Games-Tournament.Tesis. Program Studi Pendidikan Matematika Pascasarjana Universitas Negeri Medan: Medan. (2013)

[15] Rajagukguk,W. Dkk.: Merancang Inovasi Pembelajaran melalui Pengintegrasian Teknologi Informasi dan Komunikasi (ICT) pada Model-Model Pembelajaran Matematika. Makalah disajikan pada seminar Nasional Inovasi Pembelajaran pada tanggal 6 Feb 2013 di UNIMED. (2013)

[16] Ruseffendi.: Dasar-Dasar Penelitian Pendidikan dan Bidang Non-Eksakta Lainnya. Cipta Karya, Semarang Press: Semarang. (2012)

[17] Suhendra.: Pengaruh Pendekatan Pembelajaran dan Kontrol Lokus terhadap Kemampuan Penalaran Matematika SMP. Tesis pada FMIPA Unimed Medan. Tidak dipublikasikan (2015)

[18] Sudjana, N.: Penilaian Hasil Proses Belajar Mengajar.Bandung: PT.Remaja Rosdakarya (2000)

[19] Sudjana.: Metoda Statistika. Bandung: Tarsito (2002)

[20] Sumarmo, U.: Berfikir dan Disposisi Matematik: Apa, Mengapa, dan Bagaimana Dikembangkan pada Peserta Didik. Artikel Jurnal. Bandung : UPI (2015)

[21] Suryadi, D.: Penggunaan Pendekatan Pembelajaran Tidak Langsung serta Pendekatan Gabungan Langsung dan Tidak Langsung dalam Rangka Meningkatkan Kemampuan Berpikir Matematik Tingkat Tinggi Siswa SLTP. Tesis PPS UPI Bandung: Tidak diterbitkan (2010) 